\title{
Microcrystalline-Silicon-Oxide-Based N-Type Reflector Structure in Micromorph Tandem Solar Cells
}

\author{
Chiung-Nan Li, Hsuan-Yin Fang, Yu-Hung Chen, Chun-Ming Yeh, Chian-Fu Huang, \\ Yu-Chih Wang, Kai-Hsiang Hung, Yen-Yu Pan, Chien-Liang Wu, Yu-Ru Chen, \\ Jun-Chin Liu, and Chun-Heng Chen
}

Photovoltaic Technology Division, Green Energy and Environment Research Laboratories, Industrial Technology Research Institute, Hsinchu 31040, Taiwan

Correspondence should be addressed to Yu-Hung Chen, yhchen@itri.org.tw

Received 21 October 2011; Accepted 14 December 2011

Academic Editor: Shahed Khan

Copyright (C) 2012 Chiung-Nan Li et al. This is an open access article distributed under the Creative Commons Attribution License, which permits unrestricted use, distribution, and reproduction in any medium, provided the original work is properly cited.

\begin{abstract}
$\mathrm{N}$-type microcrystalline silicon oxide thin films $\left(\mathrm{n}-\mu \mathrm{c}-\mathrm{SiO}_{x}: \mathrm{H}\right)$ have been deposited by VHF-PECVD $(40 \mathrm{MHz})$ with reactant gas mixtures of $\mathrm{CO}_{2} / \mathrm{SiH}_{4}$ and $\mathrm{H}_{2} . \mathrm{N}-\mu \mathrm{c}-\mathrm{SiO}_{x}$ thin films exhibiting low refractive index value $\left(\mathrm{n}_{600 \mathrm{~nm}} \sim 2\right)$, and medium/high conductivity ( $\left.\geqq 10^{-9} \mathrm{~S} / \mathrm{cm}\right)$ are suitable to be used as an " $n$-type reflector" in micromorph tandem solar cells. Transmission electron microscopy (TEM) results show that microstructures of $\mathrm{n}-\mu \mathrm{c}-\mathrm{SiO}_{x}: \mathrm{H}$ thin films contain nanocrystalline Si particles, which are randomly embedded in the $\mathrm{a}-\mathrm{SiO}_{x}$ matrix. This specific microstructure provides $\mathrm{n}-\mu \mathrm{c}-\mathrm{SiO} x: \mathrm{H}$ thin films excellent optoelectronic properties; therefore, $\mathrm{n}-\mu \mathrm{c}-\mathrm{SiO}_{x}: \mathrm{H}$ thin films are appropriate candidates for " $n$-type reflector" structures in Si tandem solar cells.
\end{abstract}

\section{Introduction}

Microcrystalline hydrogenated silicon oxide $\left(\mu \mathrm{c}-\mathrm{SiO}_{x}: \mathrm{H}\right)$ thin films have been widely investigated due to their outstanding optoelectronic properties, such as wideband gap (low light absorption in the visible range) and high photo/dark conductivity [1-3]. By adjusting plasmaenhanced chemical vapor deposition (PECVD) processing of $\mathrm{n}$-type $\mu \mathrm{c}-\mathrm{SiO}_{x}: \mathrm{H}\left(\mathrm{n}-\mu \mathrm{c}-\mathrm{SiO}_{x}: \mathrm{H}\right)$ thin films, a wide range of optical band gap and electrical conductivity can be obtained, which primarily depends on the amount of oxygen incorporated inside and their relative microstructures. Therefore, this material draws much attention and has been used in many photovoltaic applications $[4,5]$. One of the optical applications in photovoltaics is that it can be inserted between a-Si/ $\mu \mathrm{c}-\mathrm{Si}$ micromorph tandem solar cells as an intermediate reflector structure (IRS) due to its relatively low refractive index [4]. The purpose of applying intermediate reflectors in Si thin-film tandem solar cells is that a thin aSi top cell is needed to minimize its inherent light-induced degradation of amorphous material. Therefore, more light has to be reflected back from the intermediate reflector and then absorbed in a-Si top cells to enhance their shortcircuit current densities $\left(J_{s c}\right)$. In this paper, we first present optoelectronic properties of $\mathrm{n}-\mu \mathrm{c}-\mathrm{SiO}_{x}: \mathrm{H}$ thin films and their microstructural features were characterized by transmission electron microscopy (TEM) techniques. Secondly, a-Si/ $\mu$ cSi tandem solar cells with IRS were modified to " $n$-type reflector" structures (NRS) by incorporating specific $\mathrm{n}-\mu \mathrm{c}$ $\mathrm{SiO}_{x}: \mathrm{H}$ thin films, which simplifies the process complexity of modern a-Si/ $\mu \mathrm{c}-\mathrm{Si}$ tandem solar cells. As shown in Figure 1, the " $n$-type reflector" (NR) can efficiently reflect incident visible light (500 800 nm, primarily) backward and also forms the n-type active layer for a-Si top cells, which ideally creates a tunneling junction with bottom $\mu \mathrm{c}$-Si p-layers. This $\mathrm{n}-\mathrm{p}$ tunneling junction must provide good carrier recombination paths (for electrons from top cells and holes from bottom cells) and maintains a low series resistance for a-Si/ $\mu c-S i$ tandem solar cells. Finally, cell parameters and 


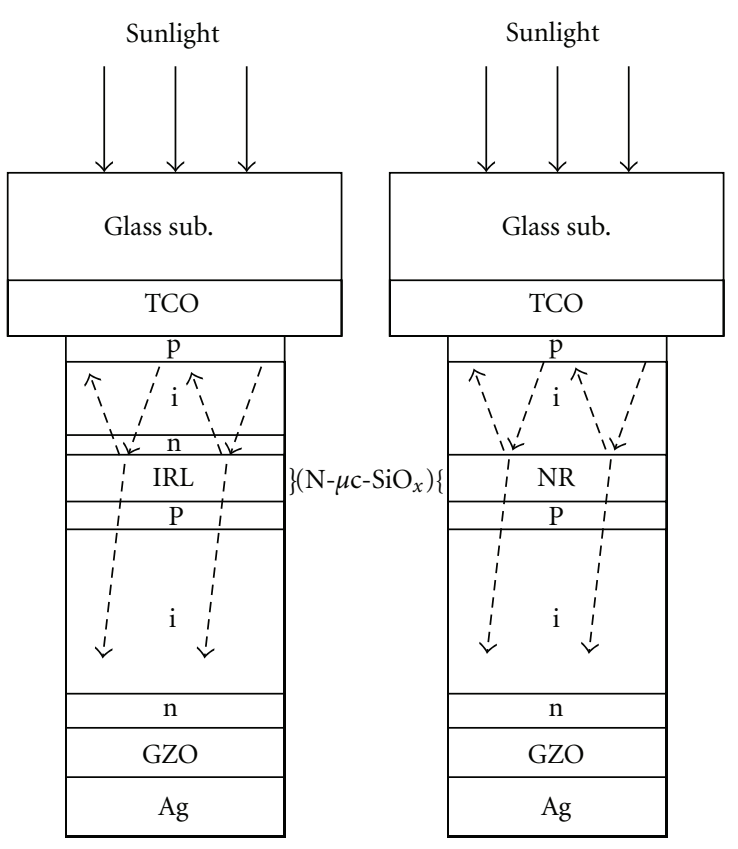

FIGURE 1: a-Si/ $\mu \mathrm{c}-\mathrm{Si}$ micromorph tandem solar cells with an intermediate reflector structure (IRS) or a " $n$-type reflector" structure (NRS) by incorporating specific $\mathrm{n}-\mu \mathrm{c}-\mathrm{SiO}_{x}: \mathrm{H}$ thin films.

respective external quantum efficiency (EQE) spectrum were also present to verify the adaptation of NRS.

\section{Experimental}

Silicon micromorph tandem solar cells were fabricated by using very high-frequency plasma-enhanced chemical vapor deposition (VHF-PECVD, $40 \mathrm{MHz}$ ) at $200^{\circ} \mathrm{C}$ to deposit $\mathrm{Si}$ thin films and pulsed dc magnetron sputtering for electrodes. The intermediate reflector/layer and n-type reflector $(\mathrm{n}-\mu \mathrm{c}-$ $\mathrm{SiO}_{x}: \mathrm{H}$ thin films) were also deposited by the VHF-PECVD technique employing reactant gas mixtures of $\mathrm{H}_{2} / \mathrm{SiH}_{4}, \mathrm{PH}_{3}$, and $\mathrm{CO}_{2}\left(\mathrm{PH}_{3} / \mathrm{SiH}_{4}=0.025\right)$. The final cell structures are "Asahi glass substrate (U type)/a-Si top cell $(\sim 300 \mathrm{~nm}$, w/or w/o Si n-layer $) / \mathrm{n}-\mu \mathrm{c}-\mathrm{SiO}_{x}: \mathrm{H}$ layer/ $\mu \mathrm{c}-\mathrm{Si}$ bottom cell $(\sim$ $3 \mu \mathrm{m}) / \mathrm{ZnO}: \mathrm{Ga} / \mathrm{Ag}^{\prime \prime}$.

$\mathrm{n}-\mu \mathrm{c}-\mathrm{SiO}_{x}: \mathrm{H}$ thin films were deposited on bare glass (Corning Eagle 2000) to determine their optical and electrical properties. Crystalline volume fraction (crystallinity; $\mu \mathrm{c} \%$ ) of $\mathrm{n}-\mu \mathrm{c}-\mathrm{SiO}_{x}: \mathrm{H}$ thin films is deduced from integral intensities of deconvoluted Gaussian bands in Raman spectroscopy (excitation at $514.5 \mathrm{~nm}$ of an $\mathrm{Ar}^{+}$laser). From the empirical equation, $\mu \mathrm{c} \%=I_{c} /\left(I_{a}+I_{c}\right)$, where $I_{a}$ is the integral intensity of the Gaussian band with its peak near $480 \mathrm{~cm}^{-1}$ for a-Si, and $I_{c}$ is the sum of integral intensities from two Gaussian bands with peaks at $500 \sim 510 \mathrm{~cm}^{-1}$ and $515 \sim$ $518 \mathrm{~cm}^{-1}$ for crystalline Si. Transmittance and reflectance spectra of $\mathrm{n}-\mu \mathrm{c}-\mathrm{SiO}_{x}: \mathrm{H}$ thin films were measured by UVVIS-NIR photospectrometer (Perkin-Elmer 1750) within a spectral range from 300 to $1200 \mathrm{~nm}$, and then optically simulated to calculate the relative refractive index, $n$ and $k$ values. The dark conductivities $(\sigma)$ of $\mathrm{n}-\mu \mathrm{c}-\mathrm{SiO}_{x}: \mathrm{H}$ thin films were measured by the four-point probe method with a pair of Ag coplanar electrodes on their surface under vacuum $<10^{-3}$ torr at room temperature.

Microstructures of $\mathrm{n}-\mu \mathrm{c}-\mathrm{SiO}_{x}: \mathrm{H}$ thin films were characterized by transmission electron microscopy (JEOL, JEM2100F; $200 \mathrm{keV})$. I- $V$ tests of silicon micromorph tandem solar cells $\left(1 \times 1 \mathrm{~cm}^{2}\right)$ were performed under AM1.5 illumination (1 Sun) at room temperature, and EQE spectrum of each subcell was measured to determine their $J_{\text {sc }}$.

In Raman spectroscopy, the peak at $\sim 480 \mathrm{~cm}^{-1}$ represents the transverse optical (TO) mode in a-Si:H and have a broad full width at half maximum (FWHM). On the other hand, the Raman peak of ideal crystalline $\mathrm{Si}$ is located around $520 \mathrm{~cm}^{-1}$, which is the position of the TO mode in crystalline Si. However, disorder and/or the size of $\mathrm{Si}$ crystallites may make a deviation of the peak position from $520 \mathrm{~cm}^{-1}$, and it has been widely discussed in research [610]. Afterward, Xia et al. [11] and Islam and Kumar [12] further incorporated the influence of Si nanocrystallite size distributions into the Raman analysis and demonstrated that extra Raman peaks exist with their peak positions shifting to lower frequency. In this paper, we also included a Gaussian band with Raman peaks at $500 \sim 510 \mathrm{~cm}^{-1}$ to calculate crystalline volume fractions of $\mathrm{n}-\mu \mathrm{c}-\mathrm{SiO}_{x}: \mathrm{H}$ thin films. The intermediate lower frequency band is associated with Raman scattering from nanocrystal boundaries and/or disorder crystalline Si arrangements $[11,13,14]$. Therefore, we estimated the crystalline volume fraction of $\mathrm{n}-\mu \mathrm{c}-\mathrm{SiO}_{x}: \mathrm{H}$ thin films from the empirical relation: $\mu \mathrm{c} \%=I_{c} /\left(I_{c}+\right.$ $\left.I_{a}\right) ; I_{c}=$ the sum of integrated intensities from two Gaussian Raman bands with peak positions at $\sim 516 \mathrm{~cm}^{-1}$ and $500 \sim$ $510 \mathrm{~cm}^{-1} ; I_{a}=$ the integrated intensity of the Gaussian Raman band with its peak near $480 \mathrm{~cm}^{-1}$.

\section{Results and Discussion}

Increasing the hydrogen dilution of $\mathrm{n}-\mu \mathrm{c}-\mathrm{SiO}_{x}: \mathrm{H}$ thin films depositions enhances the crystallinity themselves. As shown in Figure 2(a), there is a very low crystalline volume fraction of thin films ( amorphous, $\mu \mathrm{c} \% \sim 0)$ for $\left[\mathrm{CO}_{2}\right] /\left[\mathrm{SiH}_{4}\right]$ $\left(R=\left[\mathrm{CO}_{2}\right] /\left[\mathrm{SiH}_{4}\right]\right.$ : ratios of $\mathrm{CO}_{2}$ flow rates to silane flow rates $)=2.33 \sim 3.33$ when the hydrogen gas flow rate $\left(\left[\mathrm{H}_{2}\right]\right)$ that is fixed at $600 \mathrm{sccm}$ during the CVD process. However, by increasing hydrogen dilution during the deposition of $\mu \mathrm{c}-\mathrm{SiO}_{x}: \mathrm{H}$ thin film, a great enhancement of crystallinity is obtained in Figure 2(b). For example, crystallinity of n$\mu \mathrm{c}-\mathrm{SiO}_{x}: \mathrm{H}$ thin films deposited with $\left[\mathrm{H}_{2}\right]=900 \mathrm{sccm}$ and $R=2.83 \sim 3.33$ reaches near $40 \%$, as compared with that $\sim 0 \%$ when they are deposited with $\left[\mathrm{H}_{2}\right]=600 \mathrm{sccm}$ and $R=2.33 \sim 3.33$. In addition, crystallinity of $\mathrm{n}-\mu \mathrm{c}-\mathrm{SiO}_{x}: \mathrm{H}$ thin films also strongly depends on the amount of oxygen incorporated inside the $\mu \mathrm{c}-\mathrm{SiO}_{x}: \mathrm{H}$ thin films. As shown in Figure 2(a), while $R$ values continue decreasing, from 3.33 to 1.33 , a narrower Raman band with its peak at $\sim 516 \mathrm{~cm}^{-1}$ gradually appears, which shows an increase of crystalline volume fraction of $\mathrm{Si}$ crystallites in the $\mathrm{n}-\mu \mathrm{c}-\mathrm{SiO}_{x}: \mathrm{H}$ thin films with lower amounts of oxygen. 


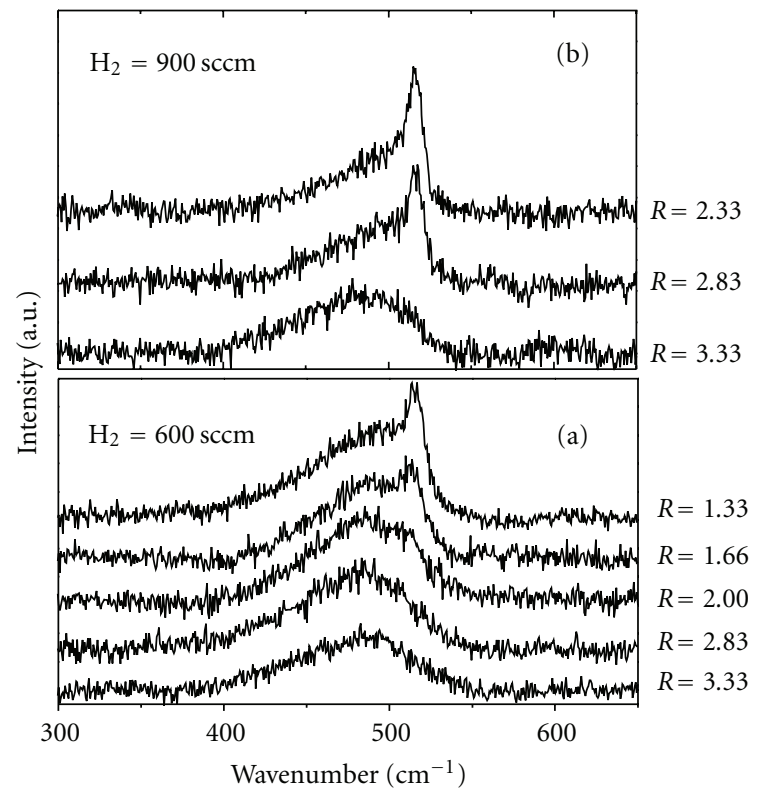

Figure 2: Raman spectra of $\mathrm{n}-\mu \mathrm{c}-\mathrm{SiO}_{x}: \mathrm{H}$ thin films deposited with $R=8 \sim 20$ under different hydrogen dilution.

Figure 3 shows the refractive index $\left(\mathrm{n}_{600 \mathrm{~nm}}\right)$, dark conductivity, and crystalline volume fraction of $\mathrm{n}-\mu \mathrm{c}-\mathrm{SiO}_{x}: \mathrm{H}$ thin films, which are deposited with varied reactant flow rate ratios of $\left[\mathrm{CO}_{2}\right] /\left[\mathrm{SiH}_{4}\right]$ and $\left[\mathrm{H}_{2}\right]$. As the hydrogen flow rate is fixed to $600 \mathrm{sccm}, \mathrm{n}-\mu \mathrm{c}-\mathrm{SiO}_{x}: \mathrm{H}$ thin films deposited with $R<2$ show an abrupt increase of dark conductivity, from $10^{-10} \mathrm{~S} / \mathrm{cm}$ to $10^{-6} \mathrm{~S} / \mathrm{cm}$, which accompanies with a boost of crystalline volume fraction of thin films $(\mu \mathrm{c} \%=20 \sim 30 \%)$. On the other hand, the refractive index of $\mathrm{n}-\mu \mathrm{c}-\mathrm{SiO}_{x}: \mathrm{H}$ thin films varies gradually, increasing from 1.8 to 2.1 , during the whole gas flow range of $\left[\mathrm{CO}_{2}\right] /\left[\mathrm{SiH}_{4}\right]$. Another set of data in this figure (open symbols) show that as the hydrogen flow rate increases to $900 \mathrm{sccm}$ with $R=2.33 \sim 2.83$, crystalline volume fraction of $\mathrm{n}-\mu \mathrm{c}-\mathrm{SiO}_{x}: \mathrm{H}$ thin films rises to a high value $\sim 40 \%$, and a great enhancement of dark conductivity of thin films is also obtained ( $>2$ order). However, when the hydrogen gas flow increases from 600 to $900 \mathrm{sccm}$ with same $R$ values, the change of $\mathrm{n}_{600 \mathrm{~nm}}$, is quite small $(\Delta n<0.1)$. Optical band gap $\left(E_{04}\right)$ of $\mathrm{n}-\mu \mathrm{c}-\mathrm{SiO}_{x}: \mathrm{H}$ thin films (derived from transmittance/reflectance spectrum), deposited with fixed $\left[\mathrm{H}_{2}\right]=600 \mathrm{sccm}$, changes from 2.48 to $2.78 \mathrm{eV}$ (as $R=1.33 \sim 3.33$ ), which shows high optical band gap energy ( $R$ dependent) and low optical absorption of $\mathrm{n}-\mu \mathrm{c}-\mathrm{SiO}_{x}: \mathrm{H}$ thin films within the visible light spectrum.

Figures 4(a) and 4(b) show the TEM bright field and dark field images of $\mathrm{n}-\mu \mathrm{c}-\mathrm{SiO}_{x}: \mathrm{H}$ thin films deposited on glass substrates. The inset of Figure 4(b) shows the selective area diffraction (SAD) pattern of $\mathrm{n}-\mu \mathrm{c}-\mathrm{SiO}_{x}: \mathrm{H}$ thin films, and it is characterized by TEM crystallographic analysis, which identifies a Si crystalline phase, for example, Si (111), (311), and (400) for the first three rings, existing inside n- $\mu \mathrm{c}$ $\mathrm{SiO}_{x}: \mathrm{H}$ thin films. The dark field image of Figure 4(b) shows that the distribution of Si nanocrystallites in the $\mathrm{n}-\mu \mathrm{c}-\mathrm{SiO}_{x}: \mathrm{H}$ thin films represents a random type and also clusters of

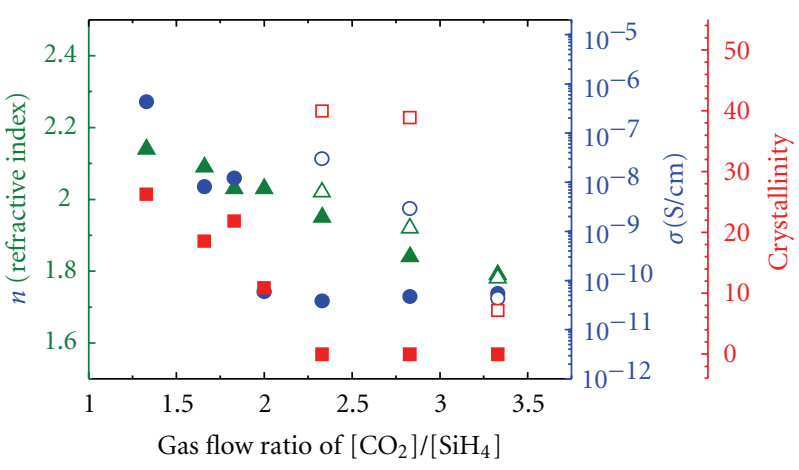

Figure 3: Physical properties of $\mathrm{n}-\mu \mathrm{c}-\mathrm{SiO}_{x}: \mathrm{H}$ thin films (thickness $=$ $40 \sim 50 \mathrm{~nm}$ ) with $R=8 \sim 20$ under $\left[\mathrm{H}_{2}\right]=600 \mathrm{sccm}$ (filled symbols) and $900 \mathrm{sccm}$ (open symbols). ( $\Delta$, and $\boldsymbol{\Delta}$ : refractive index, $n ; \square$, and $\boldsymbol{\square}$ : crystallinity; $\circ$, and $\bullet$ : dark conductivity).

nanocrystallites exist in the oxygen-rich amorphous matrix. As for high-resolution TEM (HRTEM) images in Figure 4(d), we demonstrated Si nano-crystallites with their sizes 2 $10 \mathrm{~nm}$ inside the n-type reflector layer of a-Si/ $\mu \mathrm{c}-\mathrm{Si}$ tandem cells; similar results are obtained as $\mathrm{n}-\mu \mathrm{c}-\mathrm{SiO}_{x}: \mathrm{H}$ thin films were deposited on bare glass substrates (not shown).

He et al. [15] investigated the conduction mechanism of hydrogenated nanocrystalline Si films and concluded that the high conductivity of nanocrystalline Si films results mainly from the electrical conduction between Si crystallites. As shown in Figures 3 and 4, electrical conductivity of $\mathrm{n}-\mu \mathrm{c}-$ $\mathrm{SiO}_{x}: \mathrm{H}$ thin films depends on the density of the randomly dispersed nanocrystalline Si phase, which is proportional to their crystalline volume fractions; in addition, the doping efficiency of crystalline $\mathrm{Si}$ is usually higher than the amorphous $\mathrm{SiO}_{x}: \mathrm{H}$ phase, which may enhance the conductivity of $\mathrm{n}-\mu \mathrm{c}-\mathrm{SiO}_{x}: \mathrm{H}$ thin films further as compared with that of $\mathrm{n}-\mathrm{a}-\mathrm{SiO}_{x}: \mathrm{H}$ thin films. Also, the refractive index, $\mathrm{n}_{600 \mathrm{~nm}}$, of $\mathrm{n}-\mathrm{a}-\mathrm{SiO}_{x}: \mathrm{H}$ thin films strongly depends on the amount of $\mathrm{a}-\mathrm{SiO}_{x}: \mathrm{H}$ phase, which lower the values of $\mathrm{n}_{600 \mathrm{~nm}}$ to $~$ 2. All these unique optoelectronic characteristics discussed above make $\mathrm{n}-\mu \mathrm{c}-\mathrm{SiO}_{x}: \mathrm{H}$ have thin films high electrical conductivity and transparency; thus they are suitable to be applied in NRS of thin film solar cells.

Three types of a-Si/ $\mu \mathrm{c}-\mathrm{Si}$ tandem cells were measured under AM1.5 $\left(100 \mathrm{~mW} / \mathrm{cm}^{2}\right)$ illumination at room temperature, which are standard a-Si/ $\mu \mathrm{c}-\mathrm{Si}$ tandem cells (without IRS and/or NRS), and cells with IRS and NRS. N- $\mu \mathrm{c}-\mathrm{SiO}_{x}: \mathrm{H}$ thin films with excellent optoelectronic properties $(\sigma \sim 6 \times$ $10^{-8} \mathrm{~S} / \mathrm{cm} ; \mu \mathrm{c} \% \sim 40 \% ; t \sim 50 \mathrm{~nm} ; \mathrm{n}_{600} \mathrm{~nm} \sim 2 ;\left[\mathrm{PH}_{3}\right] /\left[\mathrm{SiH}_{4}\right]$ $=0.043$ ) are used as light reflectors in IRS and NRS tandem solar cells. The ability of light reflection from IRS or NRS is proportional to the product of $(\Delta n \cdot t)$, where $\Delta n$ is the variance in index of refraction between the reflector and the surrounding Si layers, and $t$ is the thickness of the reflector. In our case, we need the thickness of $\mathrm{n}-\mu \mathrm{c}-\mathrm{SiO}_{x}: \mathrm{H}$ thin film $\left(\mathrm{n}_{600 \mathrm{~nm}} \sim 2\right)>40 \mathrm{~nm}$ to be an effective light reflector in the wavelength region 500 to $800 \mathrm{~nm}$. Table 1 displays $I$ $V$ parameters of these a-Si/ $\mu \mathrm{c}-\mathrm{Si}$ tandem cells. As in our standard cells, the $J_{s c}$ of a-Si top cells does not match well 


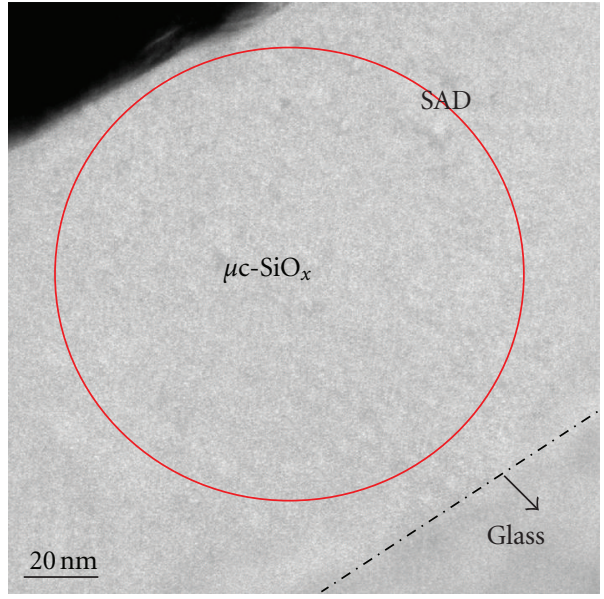

(a)

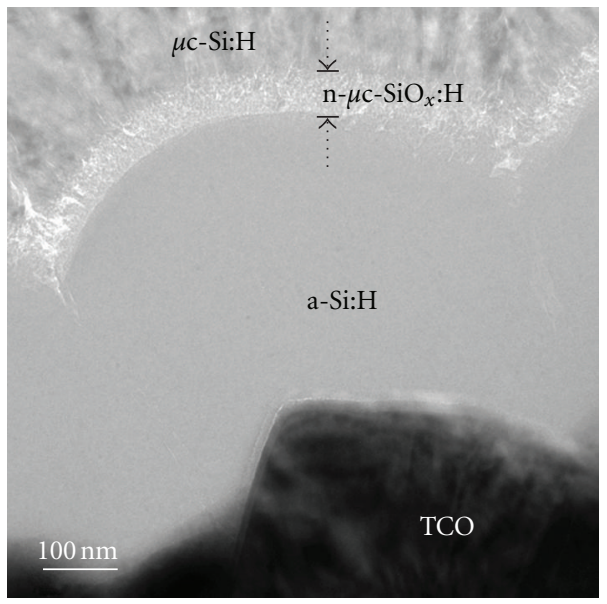

(c)

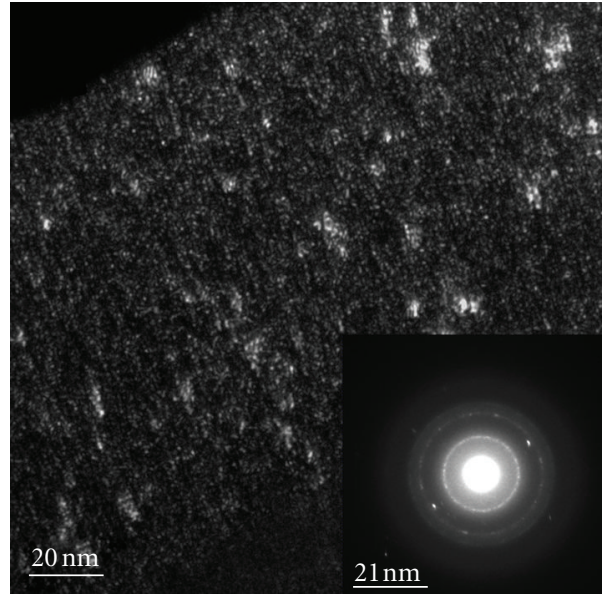

(b)

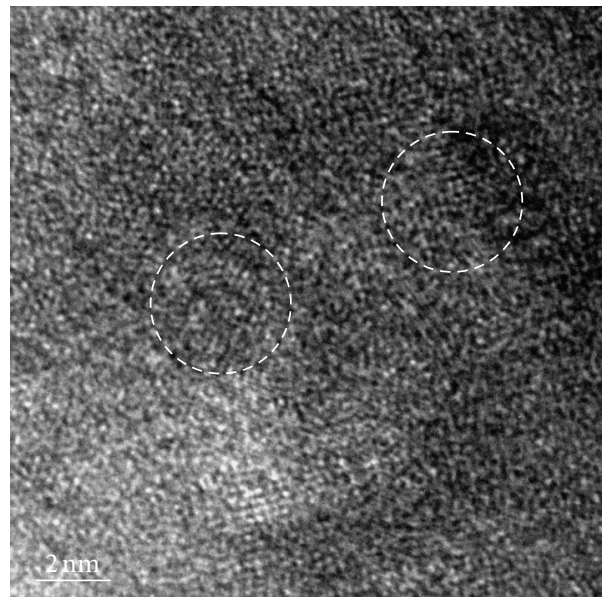

(d)

Figure 4: TEM bright field images (a) and dark field images (b) of $\mathrm{n}-\mu \mathrm{c}-\mathrm{SiO}_{x}: \mathrm{H}$ thin films deposited on glass substrates (100 KX). The dark field image is taken by the $\mathrm{Si}(111)$ diffraction (c); TEM bright field images of a-Si/ $\mu \mathrm{c}$-Si tandem cells $(25 \mathrm{KX})$; (d) HRTEM images of the $\mathrm{N}$-reflector (n- $\mu \mathrm{c}-\mathrm{SiO}_{x}$ thin films, $\left.800 \mathrm{KX}\right)$.

with that of $\mu \mathrm{c}$-Si bottom cells (top-cell current limited); thus, the net $J_{\mathrm{sc}}$ and energy conversion efficiency of tandem cells are relatively low. Conventional tandem cells with IRS will have more light reflected $(500 \sim 800 \mathrm{~nm}$, Figure 5) from the intermediate reflector $\left(\mathrm{n}-\mu \mathrm{c}-\mathrm{SiO}_{x}: \mathrm{H}\right.$ thin films) to the a-Si top cells; therefore, more light can be absorbed in top cells to improve the total $J_{s c}$ of tandem cells. Due to the high conductivity and excellent optical properties of $\mathrm{n}-\mu \mathrm{c}-\mathrm{SiO}_{x}: \mathrm{H}$ thin films (low absorption and low $\mathrm{n}_{600 \mathrm{~nm}}$ ), we simplify cell processing with IRS to " $n$-type reflector" structures between a-Si $/ \mu c-S i$ tandem solar cells, which can take the advantage of eliminating the $\mathrm{Si}$ n-layer processing of a-Si top cells. It is demonstrated in Table 1 and Figure 5. Comparable cell parameters are achievable for tandem cells with NRS and IRS $\left(\Delta V_{\text {oc }} \leqq 0.02 \mathrm{~V} ; \Delta J_{\text {sc }} \sim 0.15 \mathrm{~mA} / \mathrm{cm}^{2} ; \Delta\right.$ F.F. $\sim$ $1.8 \%$ ), and from EQE analyses, as shown in Figure 5, NRS tandem cells also function well in current matching as some portion of incident light between 500 and $800 \mathrm{~nm}$ can be efficiently reflected from the n-type reflector to a-Si top cells. Consequently, both NRS and IRS tandem cells accompany with a decline in QE of $\mu \mathrm{c}$-Si bottom cells within the wavelength range due to more light being reflected toward a$\mathrm{Si}$ top cells. Nevertheless, $\mathrm{n}-\mu \mathrm{c}-\mathrm{SiO}_{x}: \mathrm{H}$ thin films with dark conductivity lower than $10^{-10} \mathrm{~S} / \mathrm{cm}$ are not suitable to be used as NRS in our a-Si/ $\mu$ c-Si tandem cells, which usually show high series resistance and low fill factor (not shown). More detailed analysis about the effects of optoelectronic properties of $\mathrm{n}-\mu \mathrm{c}-\mathrm{SiO}_{x}: \mathrm{H}$ thin films (or multilayer reflector structures) on cell parameters are still undergoing.

\section{Conclusions}

In conclusion, it is present that microstructures of $\mathrm{n}$ $\mu \mathrm{c}-\mathrm{SiO}_{x}: \mathrm{H}$ thin films contain nanocrystalline $\mathrm{Si}$ particles $(2 \sim 10 \mathrm{~nm})$, which are randomly embedded in the a- $\mathrm{SiO}_{x}$ matrix. This specific microstructure provides $\mathrm{n}-\mu \mathrm{c}-\mathrm{SiO}_{x}: \mathrm{H}$ thin films sufficient dark conductivity and low refractive index, which are suitable as efficient light reflectors in a$\mathrm{Si} / \mu \mathrm{c}$-Si tandem solar cells. In $\mathrm{n}$-type reflector structures of 
TABLE 1: $I-V$ parameters of a-Si $/ \mu \mathrm{c}-\mathrm{Si}$ tandem cells $(300 \mathrm{~nm} / 3 \mu \mathrm{m})$ with "Standard structure," IRS, and NRS. $J_{\text {TOP }}$ and $J_{\text {BTM }}$ are obtained from EQE analyses, as shown in Figure 4.

\begin{tabular}{lcccccc}
\hline & $V_{\text {oc }}(\mathrm{V})$ & $J_{\text {sc }}\left(\mathrm{mA} / \mathrm{cm}^{2}\right)$ & $J_{\text {TOP }}$ & $J_{\text {BTM }}$ & F.F. $(\%)$ & Eff. $(\%)$ \\
\hline Std & 1.373 & 10.68 & 10.78 & 12.87 & 69.24 & 10.15 \\
IRS & 1.358 & 11.39 & 11.58 & 11.72 & 69.89 & 10.81 \\
NRS & 1.376 & 11.24 & 11.29 & 11.44 & 71.67 & 11.08 \\
\hline
\end{tabular}

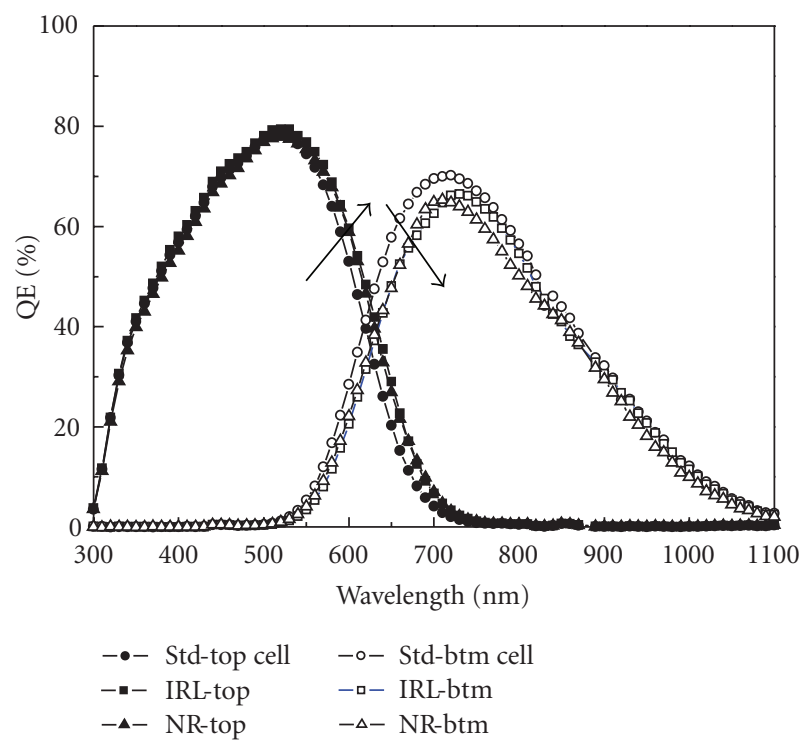

FIGURE 5: Quantum efficiency of a-Si top cells and $\mu \mathrm{c}$-Si bottom cells in three types of micromorph cells (Std., IRS, and NRS).

tandem solar cells, the $\mathrm{n}-\mu \mathrm{c}-\mathrm{SiO}_{x}: \mathrm{H}$ thin film is functioned as an activated doping layer of the top cell and simultaneously as an intermediate light reflector in a-Si/ $\mu \mathrm{c}-\mathrm{Si}$ tandem solar cells, which takes the advantage of omitting a processing step of the Si n-type layer during tandem cell fabrications. Also, we have demonstrated that silicon thin-film tandem solar cells with $\mu \mathrm{c}-\mathrm{SiO}_{x}: \mathrm{H}$-based NRS have comparable cell parameters to those with conventional intermediate reflector structures, which shows good carrier conduction at the n$\mu \mathrm{c}-\mathrm{SiO}_{x} / \mathrm{p}-\mu \mathrm{c}-\mathrm{Si}$ tunneling junction. All these results would create alternative opportunities to reduce the fabrication cost of thin film solar cells/modules.

\section{Acknowledgment}

The authors would like to thank the support from the Bureau of Energy, Ministry of Economic Affairs, Taiwan, under Grant no. A455DR1110.

\section{References}

[1] A. Sarker, C. Banerjee, and A. K. Barua, "Preparation and characterization of n-type microcrystalline hydrogenated silicon oxide films," Journal of Physics D, vol. 35, no. 11, pp. 12051209, 2002.
[2] C. Banerjee, A. Sarker, and A. K. Barua, "Comparison of structural and optoelectronic properties of n-type microcrystalline silicon and silicon oxide films with lowering of thickness," Japanese Journal of Applied Physics, vol. 41, no. 8, pp. L952L955, 2002.

[3] A. Bacioglu, A. O. Kodolbas, and O. Oktu, "Deposition of highly photoconductive wide band gap a- $\mathrm{SiO}_{\mathrm{x}}: \mathrm{H}$ thin films at a high temperature without $\mathrm{H}_{2}$-dilution," Solar Energy Materials and Solar Cells, vol. 89, no. 1, pp. 49-59, 2005.

[4] K. Yamamoto, A. Nakajima, M. Yoshimi et al., "A thin-film silicon solar cell and module," Progress in Photovoltaics, vol. 13, no. 6, pp. 489-494, 2005.

[5] P. Delli Veneri, L. V. Mercaldo, and I. Usatii, "Silicon oxide based n-doped layer for improved performance of thin film silicon solar cells," Applied Physics Letters, vol. 97, no. 2, Article ID 023512, pp. 1-3, 2010.

[6] H. Richter, Z. P. Wang, and L. Ley, "The one phonon Raman spectrum in microcrystalline silicon," Solid State Communications, vol. 39, no. 5, pp. 625-629, 1981.

[7] I. H. Campbell and P. M. Fauchet, "The effects of microcrystal size and shape on the one phonon Raman spectra of crystalline semiconductors," Solid State Communications, vol. 58, no. 10, pp. 739-741, 1986.

[8] S. Veprek, F. A. Sarott, and Z. Iqbal, "Effect of grain boundaries on the Raman spectra, optical absorption, and elastic light scattering in nanometer-sized crystalline silicon," Physical Review B, vol. 36, no. 6, pp. 3344-3350, 1987.

[9] Z. Sui, P. P. Leong, I. P. Herman, G. S. Higashi, and H. Temkin, "Raman analysis of light-emitting porous silicon," Applied Physics Letters, vol. 60, no. 17, pp. 2086-2088, 1992.

[10] H. Munder, C. Andrzejak, M. G. Berger et al., "A detailed Raman study of porous silicon," Thin Solid Films, vol. 221, no. 1-2, pp. 27-33, 1992.

[11] H. Xia, Y. L. He, L. C. Wang et al., "Phonon mode study of Si nanocrystals using micro-Raman spectroscopy," Journal of Applied Physics, vol. 78, no. 11, pp. 6705-6708, 1995.

[12] M. N. Islam and S. Kumar, "Influence of crystallite size distribution on the micro-Raman analysis of porous $\mathrm{Si}$," Applied Physics Letters, vol. 78, no. 6, pp. 715-717, 2001.

[13] H. S. Mavi, A. K. Shukla, S. C. Abbi, and K. P. Jain, "Raman study of amorphous to microcrystalline phase transition in $\mathrm{cW}$ laser annealed a-Si:H films," Journal of Applied Physics, vol. 66, no. 11, pp. 5322-5326, 1989.

[14] D. Das, M. Jana, and A. K. Barua, "Characterization of undoped $\mu \mathrm{c}$-SiO:H films prepared from $\left(\mathrm{SiH}_{4}+\mathrm{CO}_{2}+\mathrm{H}_{2}\right)$ plasma in RF glow discharge," Solar Energy Materials and Solar Cells, vol. 63, no. 3, pp. 285-297, 2000.

[15] Y. He, Y. Wei, G. Zheng, M. Yu, and M. Liu, "An exploratory study of the conduction mechanism of hydrogenated nanocrystalline silicon films," Journal of Applied Physics, vol. 82, no. 7, pp. 3408-3413, 1997. 


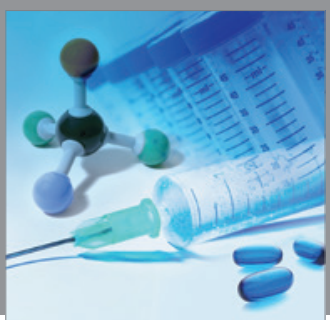

International Journal of

Medicinal Chemistry

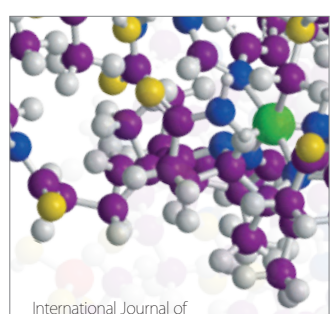

Carbohydrate Chemistry

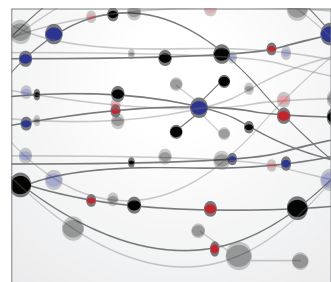

The Scientific World Journal
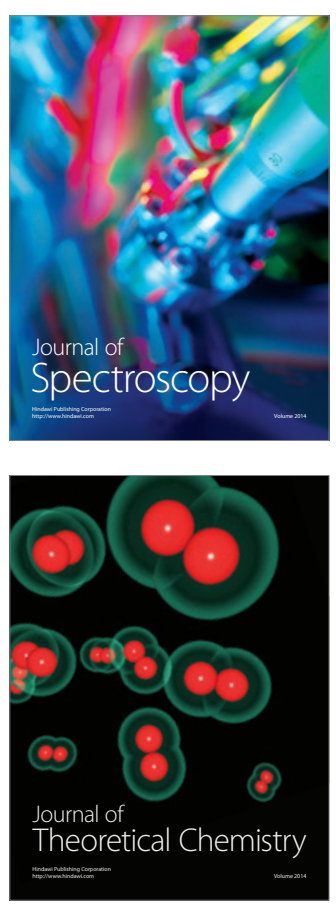
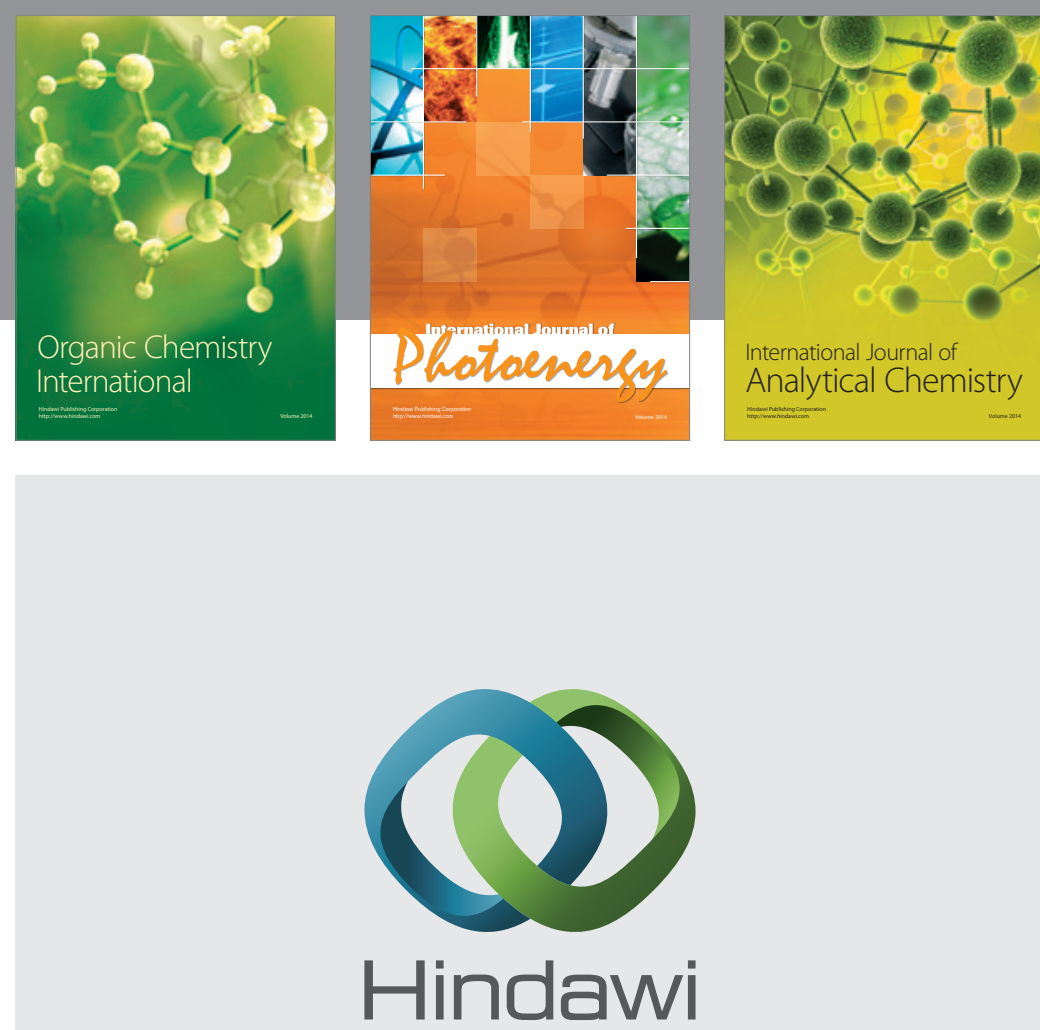

Submit your manuscripts at

http://www.hindawi.com
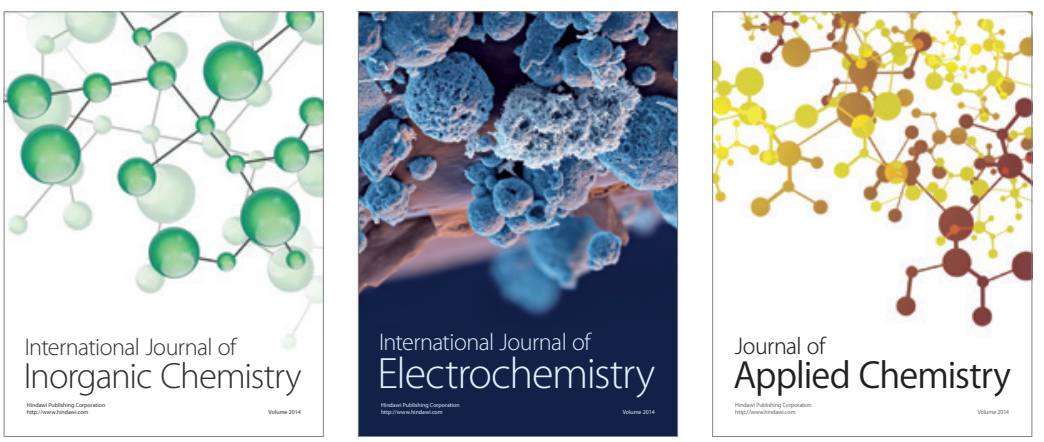

Journal of

Applied Chemistry
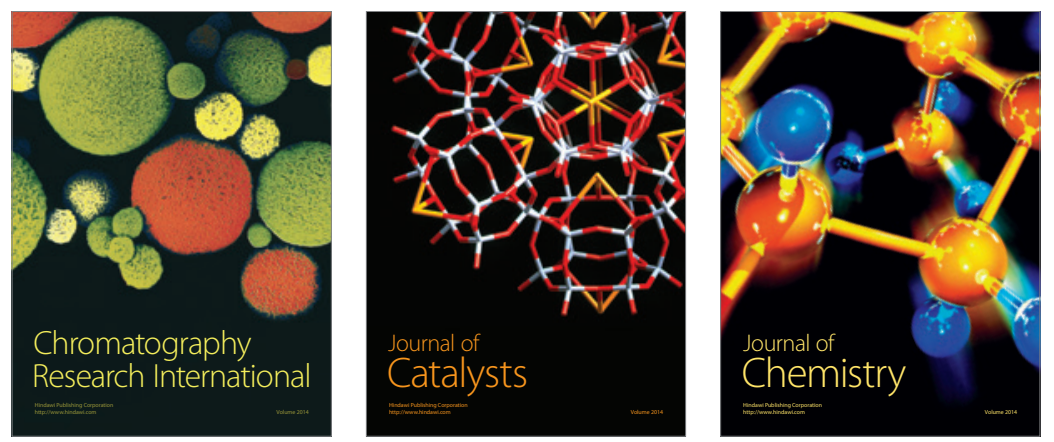
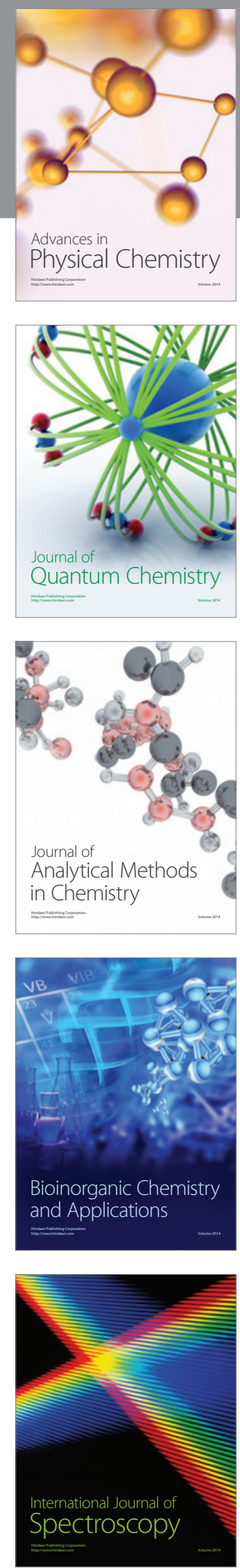